\title{
Костяева Д.В. \\ Анализ основных функций надзорного органа - губернского по городским делам присутствия на основе городового положения 1870 года
}

Ульяновский Государственный Университет (УлГУ)

(Россия, Ульяновск)

doi:10.18411/spc-20-11-2017-09

idsp: 000001:spc-20-11-2017-09

\section{Аннотация}

В данной статье анализируется основные функции надзорного органа, который был создан в ходе введения городского положения 1870 года. На основе исходного правового документа, автор статьи выявляет многофункциональность, изначально контрольного органа и определяет, что деятельность губернского по городским делам присутствия также определяется в немаловажной степени публичной функцией.

Ключевые слова: губернское по городским делам присутствие, городовое положение 1870 года, органы городского самоуправления, городская реформа, надзорный орган, публичная функция, надзорная функция.

\section{Abstract}

This paper analyzes basic functions of Supervisory authority, which was created during the introduction of city regulations 1870. Based on the original legal document, the author reveals the multi-functionality, initially the control of the authority and determines that the activities of the provincial urban Affairs presence is also determined to an important extent a public function.

Key words: provincial urban Affairs presence, the city regulations of 1870, the bodies of municipal self-government, municipal reform, the Supervisory body, public function, Supervisory function.

При обсуждении проекта городской реформы, совершено определено возникала потребность в организации дополнительного контролирующего органа на местах. С учетом расширения должностных мест в органах городского самоуправления, надзорная власть, которая была сосредоточена в руках губернатора совместно с местными органами Министерства внутренних дел, было явно недостаточно. Появилась сильная потребность в губернском органе, который мог бы осуществлять административный надзор, а именно качество проявления его функции должно включать общение с гражданами любого сословия - рассмотрение жалоб о нарушении их прав со стороны государственной и местной администрации, а также иметь право отменять незаконные решения и постановление городских дум. Идея создания описанного выше органа была предложена в отзыве на первоначальный проект городового положения главой Второго отделения Собственной Его Величества канцелярии Д.М. Сольским, предложение которого состояло в создании в губернии нового типа ведомства, который получил название «присутствие», его основной целью должно было являться защита прав и законных интересов органов местного управления и частных лиц.[1]

Таким образом, первостепенно связь между городскими и правительственными учреждениями предполагалась посредством подчинения их первому департаменту Правительствующего Сената, который в порядке, утвержденном и регламентирующей статьей 8 Городового Положения 1870 года, являлся высшей инстанцией по разрешению споров, возникших между городом и местными властями, которые связаны с исполнением общих имперских законов. [2, с.10-11] Касательно вопросов, которые связаны с реализацией собственной компетенции, органы городского самоуправления обязаны были обращаться к посредничеству губернского по городским делам присутствия в составе, определенным в статье 11 Городового положения 1870 
года.[2, с.11-16] В соответствии с которой, губернское по городским делам присутствия - это коллегиальный надзорный орган, состоящий из представителей губернской администрации (председатель губернского правления, вице-губернатор), из представителей государственных ведомств (председатель казенной палаты, губернский прокурор), из представителей общественности (председатель съезда мировых судей, председатель губернской земской управы и городского головы губернского города). Принимая во внимание тот факт, что в состав присутствия входили представители учреждений, реализовывающие правовое регулирование: председатель губернского суда, губернский прокурор.

Касательно функций, которые возлагались на губернское по городским делам присутствия, а впоследствии на губернских по земским и городским делам присутствия несли в себе строго надзорный характер.[3, с.68-73]Хотя, учитывая, что довольно большой объем ежедневной их работы был связан с обращениями граждан, которые могли не только приносить жалобы, но и прибегать к помощи присутствия. Например, учитывая повальную необразованность граждан в исходный период, и достаточно динамичное развитие законодательства, гражданину было тяжело ориентироваться, некоторым даже просто понять определенные статьи законов. Именно губернские по городским делам присутствия могли помочь гражданам и имели место обращения чиновников и руководителей, занимаемые должностные места, в растолковании и разъяснении определенных статей закона, положений и постановлений. Поэтому, возможно не осознанно, законодатель наделил, первоначально задуманный сугубо контрольный орган, еще одной немаловажной функцией - публичной. Можно предположить, что кто то из законодателей и думал о важности публичной функции, но у их не было времени сделать на ней акцент, вероятнее всего это функция образовалась вследствие отсутствия юридически-грамотного консультативного органа в регионах Российской Империи. Поэтому идеальной кандидатурой для этого рода деятельности, весьма непростой, оказался губернское по городским делам присутствия. Члены присутствия были более чем квалифицированы для оказания юридической помощи населению и городским органам самоуправления.

Таким образом, можно определить две основные функции, которые были возложены на губернское по городским делам присутствие: надзорная и публичная. Опираясь на законы, которые регламентировали организацию и деятельность данного органа власти, можно определить его надзорную функцию, как деятельность, направленную на контроль законности функционирования общественных управлений городов.

C одной стороны новый контролирующий орган должен был насторожить деятелей, имеющих либеральные взгляды, но что любопытно, именно общественные деятели того времени высказывались положительно о необходимости данного института. М.П. Щепкин считал губернское по городским делам присутствие одним из лучших нововведений реформы 1870 года. По его словам, учреждение такого присутствия могло не только послужить оплотом против единоличных решений губернаторов, но и научить коллегиальному решению возникающих вопросов, именно в этом органе М.П. Щепкин видел гарантии для общественной самостоятельности. [4, c.73] И даже такой либерал, как Б.Н. Чичерин, который всецело выступал за распространение и развитие самоуправленческих начал, высказывал точку зрения, где допускал, что вмешательство государства нужно там, где частная и общественная деятельность считается недостаточной. Но естественно, не все были настроены благосклонно в отношении нововведений, профессор Н.К. Ранненкампф уделял особое внимание неоднозначности соотношения властных полномочий губернатора и присутствия. Он подчеркивал, что очевидность того, что образованный новый орган власти губернский по городским делам присутствия ослабляет властные позиции губернатора, но при этом затрудняет понимание усиление степени губернаторского надзора, ведь опираясь на присутствие, губернатор может действовать решительнее, но нести более слабую ответственность. [5, с.98] 
Деятельность присутствия можно было трактовать как обеспечение судебной защиты городского самоуправления, но употребление данного органа в контексте органа правосудия было не совсем корректно. Поэтому имели место уточнения, ученый А.А. Головачев настаивал, что вопросы, связанные с административной практикой необходимо решать административным порядком, и нет нужды утверждать особое присутствие, так как, в случае усмотрения какой-либо незаконности действий городского управления или жалоб, пререканий, данные вопросы могли бы быть рассмотрены судом в общем порядке, в соответствии с установленным законом.[6, c.257]

При таком акценте на контрольную функцию, как с точки зрения закона, так и внимания общественности, тяжело выявить публичную функцию. Если рассматривать со стороны регламентации закона, то положения не устанавливали четкого плана работы с населением или же взаимосвязь городских органов с присутствием вне контекста надзора. Но как показала практика - активная работа с гражданами и достаточно плотная взаимосвязь с органами местной власти укрепила позиции присутствия, в качестве средства защиты интересов горожан и органов городского самоуправления. В губернское по городским делам присутствия имели право обращаться и активно пользовались этой возможностью горожане вне зависимости от сословной принадлежности, и если их требования были законными, присутствие выносило решение в их пользу. Как упоминалось ранее, по необходимости простые обыватели могли получить толкование отдельных нормативных актов, а органам городского управления присутствие могло дать рекомендации, варианты решения вопросов, возникающих при реализации законодательных актов. Согласно Городовому Положению 1870 года круг действия городского общественного управления ограничивался пределами города и отведенных ему земель.[2, с.9]Исходя из этого, взаимодействие органов городского самоуправления между собой было ограничено, соответственно информирование городских дум о прецедентах и нарушениях, случившихся в других губерниях, а также положительном опыте муниципальных и земских властей было одной из функций губернских по городским делам присутствия.

Именно многообразие функций, многие из которых раскрылись вследствие организованной и коллегиальной работы присутствия привели форму городского управления к определенным результатам, которые выражались в неуклонном росте экономического развития городов, грамотности населения, его политической активности. Являясь мостиком, соединявший два уровня власти, с противоположными взглядами, желаниями и возможностями на установления городского и земского управления, смог выстоять и провести через себя основополагающие идеи и начала муниципального права.

$$
* * *
$$

1. Российский Государственный исторический архив (далее - РГИА). Ф. 1261. Оп. 2. 1864. Д 105. Режим доступа: http://www.fgurgia.ru/imageViewer/img?url=mZaTmpGekprCl4uLj8XQ0M7IzdHNztHL0cvFxs/Gz9CNm JaeoIyLkI2emJrO0NDPz8/O0M/Pzs/Qz83PydGPm5nZnIqNjZqRi6+emJrCztmah4vCj5uZ2Z6Li43Czs/Jys 7ZjJqNlp6Tws7ZkJ2VmpyLws3Ix8/KysjL2ZiNkIqPws8= дата обращения 14.06.2017

2. Высочайше утвержденное 16-го июня 1870 года городовое положение с объяснениями. - С.Петербург: Хоз. департ. М. В. Д. , 1870. 240 с. -Режим доступа: https://www.prlib.ru/item/406020

3. Городовое положение 11 июня 1892 года с относящимися к нему узаконениями, судебными и правительственными разъяснениями / составил присяжный поверенный М. И. Мыш. - Издание 3-е, исправленное и дополненное. - С.-Петербург: типо-литография наследников И. А. Фролова, 1897. 887 с. - Режим доступа: https://www.prlib.ru/item/329765

4. Анкушева К. А., Бочанова Г. А., Дегальцева Е. А., Кириллов А. К., Ноздрин Г. А.,Шиловский М. В., Ус Л. Б. История общественного самоуправления в Сибири второй половины XIX - начала XX века. - ИД «Сова», Новосибирск, 2006. 352с.

5. Ренненкампф Н. К. Публичные лекции о новом городовом положении. - СПб., 1871. 130 с.

6. Головачев А.А. Десять лет реформ. 1861-1871. - Спб.: издание «Вестника Европы», 1872. 398 с. Режим доступа: https://www.prlib.ru/item/331217 